\title{
MLC Libraries intranet website: A collaborative process
}

\section{Jane VINER \\ Director of MLC Libraries Methodist Ladies' College Melbourne, Australia}

This paper examines the collaborative processes involved in developing the MLC Libraries intranet website and outlines helpful hints about website design, evaluation and promotion. The MLC Libraries intranet website has been designed to provide the MLC community with information resources that reflect the educational, cultural, literary and recreational needs of the college. Information resources include an online suggestion book, online teacher librarian research assistance, access to the catalogue, newspaper and magazine databases, reading lists, information literacy programs and internet search tips. MLC Libraries promote the development of information literacy and nurture an appreciation of literature in a supportive, creative and information-rich learning environment. This intranet website was created by a team of MLC teacher librarians and library staff, with technical support from a website designer and MLC computer staff. It was launched to the MLC community in March 2003. The workshop will demonstrate a virtual and visual tour of the MLC Libraries intranet website. 


\section{Introduction}

The website discussed in this paper was developed by the library website team at Methodist Ladies' College Melbourne. The MLC Libraries intranet website (hereafter known as the website) provides an extensive range of information resources and services for students and staff of the college (hereafter known as MLC). The paper provides brief background information on MLC and MLC Libraries. The sections address a range of questions 'what, who, why, how, where and when' about the development of the website from the early beginnings, through the collaborative process, to the ongoing issues including maintenance of the website. Other sections outline useful hints when developing websites, a range of MLC Libraries promotion ideas and a reflection. This paper is written from the library director's perspective.

\section{Background}

\section{Methodist Ladies’ College Melbourne}

Methodist Ladies' College Melbourne, Australia, is the largest girls' school in the southern hemisphere with more than 2000 students from MLC Kindle to Year 12. The college is divided into four schools: junior school (MLC Kindle-Year 6), junior secondary school (Year 7 and 8), middle school (Year 9 and 10) and senior school (Year 11 and 12) offering IB, VCE and VET programs. The main campus is located in Kew, five kilometres east of Melbourne, and there are two other campuses in rural Victoria--MLC Marshmead, located at Mallacoota on the far east coast of Victoria, and MLC Banksia, located on the Gippsland Lakes in south-eastern Victoria.

\section{MLC Mission Statement}

MLC is committed to providing a challenging, enriching and supportive learning environment that develops confident, articulate young women who have the skills, knowledge, values and attitudes to shape their future and contribute meaningfully to the international community. MLC will remain at the forefront of education, maintaining its Christian heritage and its commitment to sharing its vision with others. MLC will encourage each girl through involvement in the total life of the college:

1. To gain a sense of excitement in learning, and develop the ability and initiative to apply what is learned.

2. To develop high self esteem, optimism and a commitment to personal excellence.

3. To sustain an individual point of view, while respecting the rights of others, and to participate actively in decision making.

4. To gain knowledge of the religious and ethical heritage of human kind, and to develop and live by a set of values consistent with the Christian faith.

5. To develop a sense of her own cultural heritage, an understanding and appreciation of the multi-cultural nature of Australian society and its place in the world.

6. To understand the continuing contribution of women to the world, and equip her to become a full, equal and active member of our changing society. 


\section{MLC Libraries}

MLC Libraries was the name given to the group of libraries and information professionals at MLC after a change of library director in 2000 led to a new focus for the college library services. MLC Libraries saw a group of staff brought together with one focus. The two main libraries, Junior School Library and Walton Library, are staffed and offer circulation and reference services. The junior library caters for primary students and staff. The Walton Library caters for secondary students and staff, and also supports the college community with audio-visual services. The special purpose and department libraries have collections catalogued and processed by the library staff. Special purpose collections include Tiddeman Reading Room (boarder's residence) and the Marshmead Farmhouse Library. The MLC Libraries staff comprises three teamsaudio visual services, education services and technical services. Staff include: director, teacher librarians, librarian, audio visual services co-ordinator, senior library technician, audio visual technicians, library technicians and library assistants.

\section{Mission statement of MLC Libraries}

'MLC Libraries promote the development of information literacy and nurture an appreciation of literature in a supportive, creative and information-rich learning environment.’ (c) MLC Libraries 2005

The MLC Libraries mission statement, which was updated in 2005, underpins the extensive range of information resources and services the library team provide for the college community. The resources reflect the educational, cultural and recreational needs of the college.

\section{Overview of MLC Libraries intranet website}

\section{Background}

The website is designed to provide the MLC community with a virtual library containing links to a wide range of information resources and services. These include an online suggestion book and research assistance for students and staff, access to the library catalogue, newspaper and magazine databases, reading lists, pathfinders, information literacy programs and internet search strategies. There are two library websites:

- MLC Libraries webpage on the external MLC internet site

- MLC Libraries intranet for students and staff.

The external MLC site is a college marketing tool and the library webpages give brief information about the libraries' facilities but does not link to any resources on the MLC Libraries intranet website. The intranet website is password protected for security of documentation and privacy and accessible via myMLC.net, the intranet service for the college community. The library portal provides staff and students with access to a range of resources and services in their own homes after school hours and during school holidays. 


\section{Structure}

The MLC Libraries intranet website has five primary levels which are further divided into secondary and tertiary levels. The primary level headings are:

- About us

- Let's research

- Literature

- Programs

- Resources.

To access the website, a user logs onto myMLC.net, chooses the Library link on the top tool bar and clicks to open. The opening page lists the five primary levels and provides a direct link to the library catalogue, which takes the user to a keyword search and is available to all users on MLC campus. As the cursor hovers over a heading the secondary and tertiary levels of the site are displayed. The website layout, the photograph banner and the five primary links is illustrated by Figure 1 (note: the stylised star depicted in Figure 1 is not the MLC logo).

Figure 1: MLC Libraries bookmark (internal promotion tool for MLC staff)

\section{About us}

MLC Libraries--User information--Talk to us--What's on

'About us' includes the MLC Libraries mission statement, information

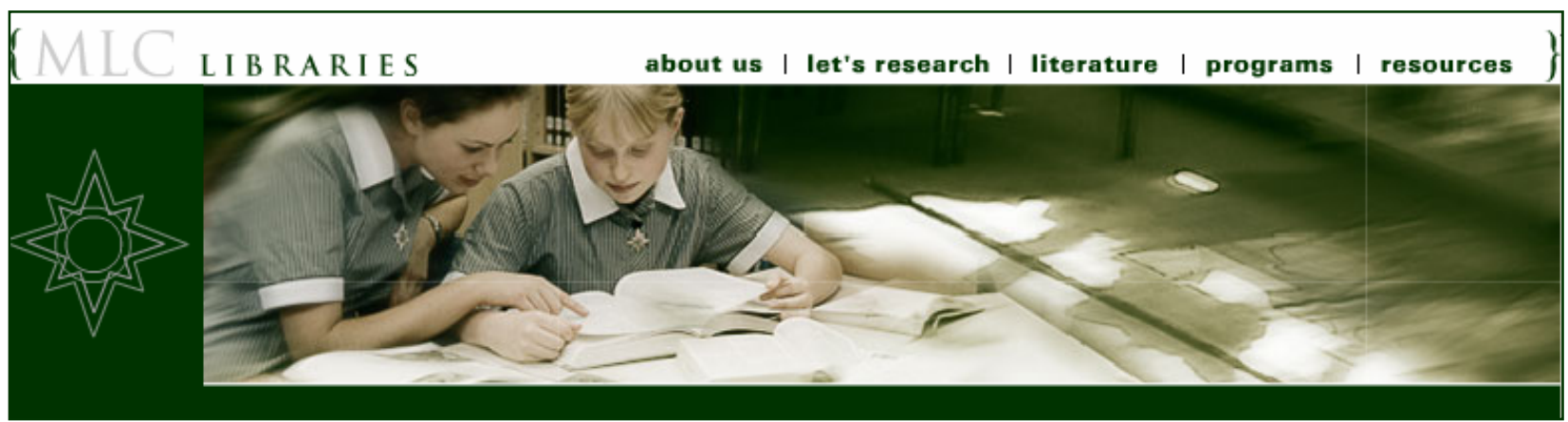

about each library, the library team, borrowing procedures, hours of operation, services, online information expert service, online suggestion service and a calendar of events. Figure 2 illustrates the layout of the first primary link 'About us' and the secondary and tertiary levels.

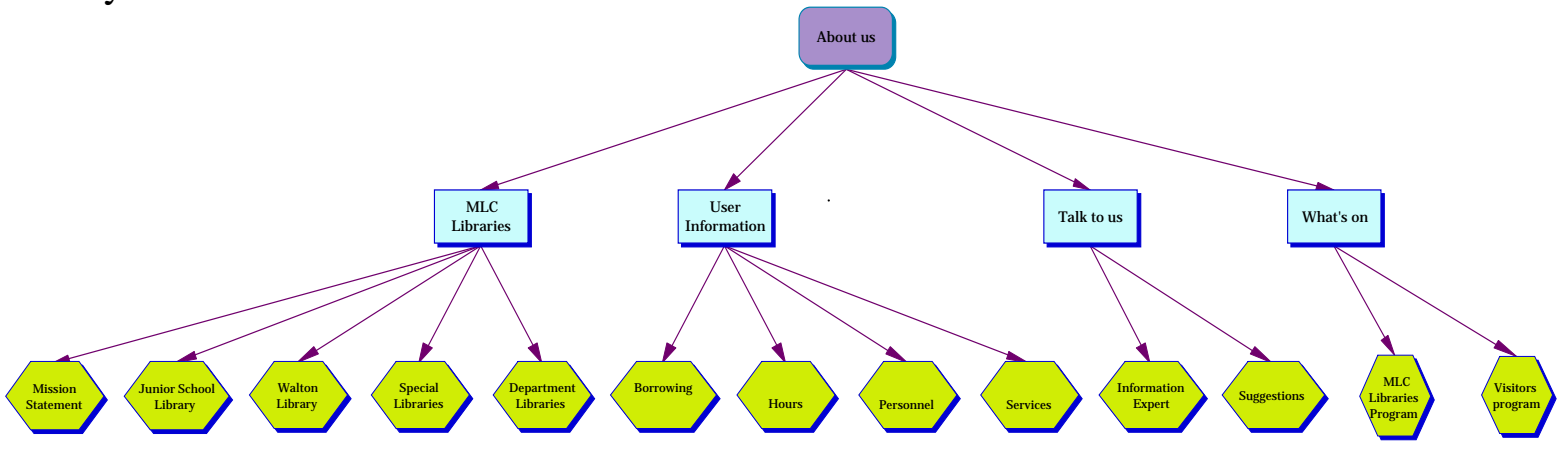

Figure 2: 'About us' diagram using Inspiration software 
The 'Talk to us' information expert service (see Figure 4) assists students and staff working on research tasks during and out of school hours. International Baccalaureate extended essay students make full use of this service during the long holiday break in December and January. One of the benefits of having an 'in-house' research service is that the staff are familiar with the curriculum-related questions posed by students. Many of the questions can be answered using the online resources embedded in the pathfinders prepared by the teacher librarians to support the curriculum.

\section{Let's research}

Copyright--Bibliographies--Pathfinders--Step-by-step

'Let's research' includes information on copyright issues and provides links to relevant copyright websites. 'Bibliographies' are described in detail for each school and clearly stated guides set out the bibliographic style to be used when citing references. This information is an invaluable resource for students and staff and especially useful for senior IB and VCE students. 'Pathfinders' are listed for year levels and curriculum areas. The pathfinders are a blueprint for a variety of resources on a specific topic and are prepared by the teacher librarians in consultation with subject teachers to meet individual curriculum needs. 'Step by step' is a guide to the research process.

\section{Literature \\ Clubs--Events--Reading lists--Reviews}

'Literature' includes library book clubs for staff and students, literature events, author visits, competitions and displays. 'Reading lists' provides lists appropriate for each year level and 'Reviews' enables students to submit literature reviews which are published monthly.

\section{Programs}

Networkers--Gateway--Orientation--Staff

'Programs' outlines information literacy programs developed and taught by the library education team. 'Networkers' is for Year 7 students. 'Gateway' is for Year 9 students. 'Orientation' explains the variety of orientation programs organised for students. 'Staff' illustrates a variety of programs organised for staff from individuals to faculty groups.

\section{Resources}

Catalogue--Online resources--Magazines--Search the net

The 'Resources' section has the main link to the library catalogue and a variety of search facilities from 'Keyword' to 'My details'. Library users can access their own borrower records via 'My details' using their Star card, the MLC photo identity, security and library smart card encoded with a microchip and barcode. 'Online resources' is the link to the subscription databases, online encyclopedias, CD-ROMs and other online resources. Students and staff working offsite are provided with passwords for access. 'Magazines' gives an overview of the collection and has a 
comprehensive list of both department and library holdings. 'Search the net' provides access to recommended search tools, tips for internet searching and a guide to websites, including the anatomy of a URL and questions to ask when evaluating websites. Figure 3 shows the questions to ask webpage from the 'Search the net' link.

\section{Questions to ask ...}

Who created the site...

- Is the name of the group or individual who created the site, clearly stated?

- Is a site map provided?

- Are users able to make comments or ask questions?

- Is information about copyright available?

Why is the site there...

- Is the site's purpose clear?

- Does the content reflect the purpose be it to educate entertain or sell?

- Does advertising overshadow the content?

- Does the site enrich the user's experience and expand the imagination?

Is this a site with personality and character...

- Is the information easy to find and use?

- Is the site visually appealing?

- Are users able to 'get around' or navigate the site easily?

- Are any links well org4anised and well chosen?

- Do the pages load in a reasonable amount of time?

- Are any multimedia features (special graphics or audio) well chosen?

- Are interactive features clearly explained?

- Do you need to pay a fee or type in personal information to use the site?

Does this site educate, inform and entertain ...

- Is the title appropriate?

- Is the content easy to read and understand by its intended audience?

- Is there enough information to make a visit worthwhile?

- Is there a search function?

- Is the spelling and grammar correct?

- Is the information current and accurate, and does it have a 'last updated' notice?

- Are there links to more information?

Source: Grassian, Esther 2000, 'Thinking critically about world wide web resources', available at <www.library.ucla.edu/libraries/college/help/critical/index.htm>, page accessed 26 September 2000.

Figure 3: Questions to ask webpage

\section{Why did MLC Libraries develop an intranet website?}

The original version of the library website was launched in 1995/1996 using pre-internet technology. At the time of its development in the mid-nineties it was a forerunner of school library websites and held in high regard as an example of a technological initiative for school libraries. Five years on and technological changes had earmarked the library website for a significant overhaul.

In 2001/2002, the college changed its policy on information being available on the internet and teaching staff were encouraged to develop curriculum or department intranet websites as part of the professional development technology program. The 
college developed three websites-an internet site for prospective families and information for external interest, intranet site for staff and students, and a parent's intranet for the parent community.

The MLC Libraries intranet website became the technology project for the library education team for Semester 2, 2002. The team comprised the library director, primary and secondary teacher librarians and the technology librarian. Discussions about the existing website revealed that with changes in technology and improved graphics, a fresh start would be the most economical way to move forward.

A decision was made to adopt a new style emphasising ease of navigation, information for the whole school, photos to reflect the college's international focus, and the new school uniform. The intranet website was to contain the most information and the internet website the least. The MLC marketing focus had changed and this new emphasis impacted on the development of the new college intranet. The aim was to ensure a more concise library website with three levels and a maximum of eight primary links.

These changes, together with the revised and new content, were discussed in detail at numerous planning meetings. The final decision was for the MLC Libraries website to have five primary links:

- About us

- Let's research

- Literature

- Programs

- Resources.

\section{What is the collaborative process and who was involved?}

Collaboration was the essential ingredient of the website development process. A range of staff were involved and collaboration occurred within the library team, with other MLC staff and with the website designer. A collaborative process underpins the MLC Libraries focus where a group of staff combined with the opinions, skills and expertise of others have benefited in working together on a worthwhile project.

Initially, the library education team, including the director, teacher librarians and the technology librarian, started the process of website review. Later, the website team was expanded to include:

- Director of MLC libraries

- teacher librarians

- technology librarian

- audio visual technician

- library/AV technician

- Director of Computing and Multimedia

- computer technicians

- Director of Marketing

- website designer. 
Members of the library education team were allocated areas of the original website to review. The old site had numerous primary links and multiple levels. Some of the content was rewritten and updated, other content was discarded.

The website team was co-ordinated by a secondary teacher librarian with organisational and diplomacy skills that were paramount to the success of the project. Other staff were called on at times throughout the process for their input and expertise, and these included the Director of Marketing, Director of Curriculum Services, teachers, library staff and other education support staff.

Student involvement has included participation in photographs, contributions to literature reviews, literature club booklists, online suggestions re library environment and use of the 'Talk to us' info expert service. This webpage is illustrated in Figure 4.

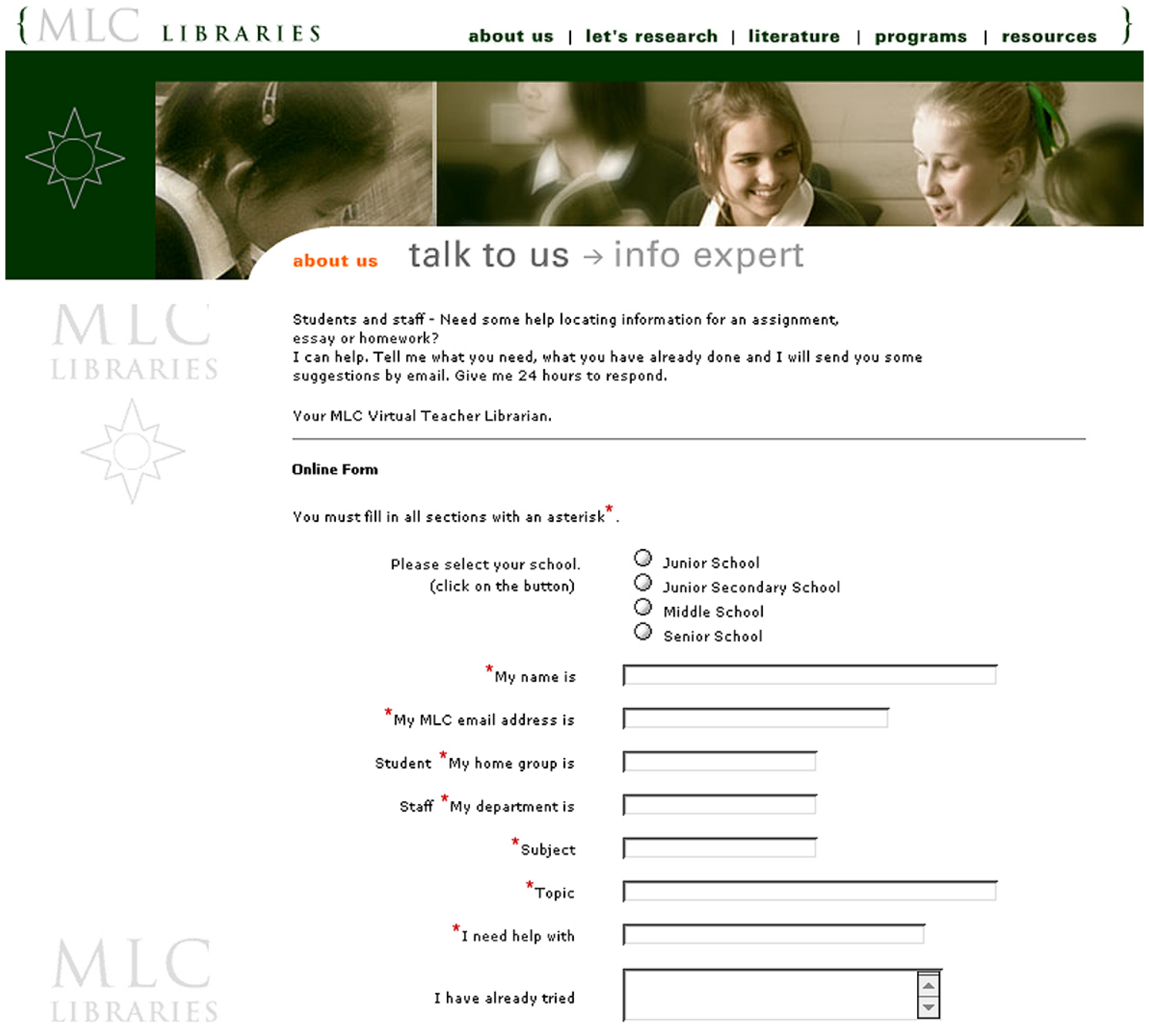

Figure 4: About us--talk to us--info expert webpage

Responsibility for each of the primary levels was given to a teacher librarian, including the director, and then divided into responsibility areas among the 
library education team. The responsible person was asked to review and evaluate the original website information and through research and discussion write and assemble new content for that section. Some of the webpage responsibility was shared, including the information for each of the secondary and tertiary levels. The primary teacher librarian was asked to build the junior school library section of the website from scratch as the original website focussed solely on the secondary library and its facilities and

\begin{tabular}{|c|c|c|}
\hline \multicolumn{3}{|c|}{ MLC Libraries intranet website webpages :Responsibilities } \\
\hline \multirow[t]{4}{*}{ About us } & Mission Statement & \\
\hline & Services & \\
\hline & Talk To Us & \\
\hline & What's on & \\
\hline \multirow[t]{4}{*}{ Let's Research } & Copyright & \\
\hline & Bibliographies & \\
\hline & Pathfinders & \\
\hline & Step by Step & \\
\hline \multirow[t]{5}{*}{ Literature } & Clubs & Lit Club E \\
\hline & & $T A B \quad P$ \\
\hline & Events & \\
\hline & Reading Lists & \\
\hline & Reviews & \\
\hline \multirow[t]{4}{*}{ Programs } & Networkers & \\
\hline & Gateway & \\
\hline & Orientation & \\
\hline & Staff & \\
\hline \multirow[t]{7}{*}{ Resources } & Catalogue & $A-Z$ \\
\hline & Electronic & Encyclopedias L/P \\
\hline & & Indexes \\
\hline & & Quick Reference K \\
\hline & & Searching the Net $C$ \\
\hline & Info Expert & \\
\hline & Magazines & \\
\hline Junior School Content $R$ & & \\
\hline
\end{tabular}

services. This information was then added to the relevant sections. Figure 5 illustrates the staff responsibilities for the webpages of the MLC Libraries intranet website.

Figure 5: MLC Libraries intranet webpage responsibilities

\section{How was the MLC Libraries intranet website developed?}

Goal--why do we need a new website?

MLC Libraries provides information services to both sectors of the MLC community. As previously mentioned the MLC marketing change of focus had a direct impact on the content and design of the website. The audience included primary students and was to cater for all MLC students and staff, not just the secondary 
population. The college already had an external library website which required updating or discarding. The library required a presence on the new college intranet to offer students and staff access to a range of information resources and services.

\section{Structure--how will the hierarchy be organised?}

To determine the hierarchy of the website and the number of levels, decisions were made about the sections and the number of primary links. In the initial discussions old-fashioned butcher's paper and sticky notes were used to record decisions about the proposed structure of the website. Once the five primary links were agreed, the next stage was to discuss headings for the secondary and tertiary levels. Hierarchical diagrams for each primary link were prepared using Inspiration software (see Figure 2). During this development phase one major decision was where to locate the link to the library catalogue. Initially it was only going to appear in the Resources section, but subsequently it was decided to also place the link on the library homepage. The teacher librarians wanted to ensure that students from early primary to senior secondary could follow the structure and easily find the information they require.

\section{Information content--what information resources and services will be} included?

A significant amount of content from the original website was discarded, but other parts were rewritten and new content developed to form the basis of each of the primary sections. An information expert for students and staff was an example of an online service offered by the teacher librarians (see Figure 4). Bibliographic content was considered essential along with pathfinders, research steps, reading lists, programs and copyright information. Explanations about borrowing, hours of operation and personnel were also included. Resources included access to a range of online resources and magazine holdings.

\section{Design--what will the website look like?}

Early discussions focussed on colour, graphics, text, fonts and logo. A decision was made to use the main school colour green and to include the colour tangerine from MLC Kindle. The photos on the banner were intended to reflect both primary and secondary students enjoyment with literature and resources. The design structure was to be simple and uncluttered to increase ease of use for the range of students from early primary to late secondary.

\section{Navigation--how will the users navigate the website?}

The teacher librarians wanted the structure of the website to unfold as the user moved their cursor over the main link. This would provide for easy navigation and enable the user to see where they were located within the site.

Task division--who will undertake each role and will we need to outsource? 
After early discussions one of the teacher librarians was asked to lead the website team. Tasks were then divided among members of the library website team. The director, teacher librarians, and a library technician prepared the content. The Director of Computing and Multimedia engaged the website designer and arranged funding. The audio visual technician took the photographs for the website banner. The technology librarian assisted the computer technicians with uploading information content. The Director of Marketing was consulted in regard to legalities re photo permissions and ensuring the website was consistent with MLC style. The website designer integrated the photos and content and brought together all the ideas into a finished package ready for uploading to the college intranet.

\section{Meetings--who will record decisions and organise regular meetings?}

The website team leader arranged meetings and recorded decisions. Documents outlining website responsibilities, structure and decisions were saved to the library server.

User testing--who will organise the testing and changes from the feedback?

The testing of the website was organised by the website team leader, the technology librarian and the computer technicians. Members of the website team and some interested staff were included in the trials. Constructive feedback assisted in solving navigational issues or improving content to ensure the website was 'userfriendly' to all library users.

Launch--when will you plan the launch and how do you communicate the new website to users? How do you replace the original website?

The website team had agreed on a launch early in Term 1 but a number of unforeseen delays led to this being postponed to mid-term. The website was in a prominent position on the college intranet and this would assist users with access to the site. A range of methods were used to promote the website and they are discussed elsewhere in the paper. One of the issues was to ensure the original website was removed from external agencies.

Review--who will organise this and will a redesign of the website be required?

The responsibility for revising and updating of the website reverted to the library education team. Two years after the launch, it is intended that a major revision be incorporated in the 2006 budget plan.

\section{When did this collaborative process begin?}

In 2000 a change of library director prompted an initial discussion about the original library website. A discussion document was prepared outlining the issues and 
problems relating to the existing site and suggested changes. The conclusion was that the library website required a complete overhaul. An important consideration in making any changes to the existing website was the time commitment of staff and the budget available. There was also the possibility of outsourcing some aspects of the work such as graphic design and web programming.

\section{Timeline}

- 2000--initial meetings to review existing website, original website updated in some aspects but form and layout remained the same, change of staff responsible for website

- 2001--updating of pathfinders and removal of outdated information, informal discussion on planning and decisions whether to update or redesign

- 2002--library website team formed, design and action plan, responsibilities and tasks allocated to website team, website designer employed, content prepared, some existing content rewritten, discussion, review, more discussion, decisions, draft

- 2003--final updates and delays resolved ready for launch, marketing to school community, professional development sessions for staff and students

- 2004--same format, updates of information as required, change of staff responsible for website maintenance

- 2005 (semester 1)--update of photos and minor content, semester 2 update plan for revision for 2006; to be included in 2006 budget

- 2006--feedback and revision.

\section{Where is the MLC Libraries intranet website located and how is it accessed?}

The website is available to all staff and students who have internet access at home. The catalogue and CD-ROMs are only accessible within the MLC campus. Students who are boarding at the college also have 24-hour, 7-day-a-week intranet and internet access from their residence.

MLC was the first school in the world to provide notebook computers for its students and staff. Students from Year 5 upwards and most teaching staff have a notebook provided by the college. These notebooks are updated every three years. A total of 2300 notebooks allow the majority of the college community to access the website in a seamless, technology-rich environment. Wireless access is available campus-wide to all staff and students with a notebook. Education support staff are provided with a desktop computer with access to the internet and MLC intranet.

\section{Factors that impact on website maintenance}

Internal changes at college and library level have an impact and can either require a large revision of a specific part or a complete edit of the entire website. Each year regular updating and maintenance is required. Internal changes to personnel and staff responsibilities can also have a significant impact on the content. Sections that require regular updating include:

- About us 
-- staffing: name changes and responsibilities updated as required

-- what's on: calendar updated each year or term

- Let's research

-- pathfinders: updated from curriculum requests from classroom teachers

- Literature

-- clubs: recent title lists added per month or term

-- reviews: monthly reviews added

- Programs

-- information literacy programs: updated as required

- Resources

-- online resources: updated each term or as required

-- magazines: updated each term or as required.

Early in 2005 the college underwent a number of changes. A significant staffing change occurred with the appointment of a Director of Curriculum 7-12. Prior to this, secondary (7-12) curriculum areas were arranged within the schools by subject. In 2005 many of these positions were made redundant with the appointment of subject heads 7-12. This focus on curriculum 7-12 inspired the library director to initiate a change in the model of curriculum support by teacher librarians. This structural change required documentation. A revision and discussion of the text by the director and the library education team was required. Change in personnel and staff responsibilities also had to be reflected on the website. A name change of media services to audio visual services also occurred. This change reflected the altered responsibilities and services for audio visual services.

In 2007, the junior school library and Years 3-6 classrooms are being rebuilt. This physical change will impact on the information services offered by the junior library staff and the description of the junior school library will need to be revised and rewritten.

Ongoing maintenance and responsibility for the website needs to be organised as part of the process. If changes in personnel occur it is important to ensure that the next person is skilled to make the necessary amendments to the website. It is essential that the website supports the aims of MLC Libraries, is up-to-date and accurate, and reflects the current personnel and services offered.

\section{Some useful ideas and hints to assist with website design}

Website development requires decisions about a range of structural issues. The structure of the site, navigation, page layout, consistency, text, identity, page length, document file size and graphics are all factors that contribute to successful website design.

\section{Structure of a site}

It is vital to consider how to structure a website before making its component pages. This is important even for the smallest site. Most sites have a main page called a 'homepage' which provides a table of contents to the other pages of the site while at the same time aiming to be aesthetically pleasing. The hierarchical structure of a website is described in terms of 'levels'. A small site with only four pages may have a homepage and three second-level pages. Large sites have many levels and users speak of 'drilling' down to obtain information. 


\section{Navigation}

Navigation is by clickable links, arrows, menus, sitemaps and navigation bars. Links should lead to the homepage, to lower level pages and same level pages on different topics. A website map is a visual hierarchical representation of all topics and pages.The user should know which organisation the website belongs to, which page they are at, where they are located, how they can return to the homepage, get to other parts quickly and how to contact the website owner or responsible organisation. The branding concept suggests that every page should have the organisation logo and demonstrate consistency. These decisions affect the structure of each page and need to be made early in the process.

\section{Page layout}

The webpage layout affects people's ability to find what they want and the ease with which they can browse the information. Users tend to scan information on websites rather than read in depth, so minimising the amount of text and providing smaller blocks can be useful. Text in columns reduces eye muscle fatigue and white space on the screen assists with clarity of the text or graphics. Once webpages are laid out, it is helpful to have standard templates available to assist the process of adding information effectively.

\section{Consistency}

Key factors such as colour, layout, logo, font and placement of major headings all contribute to the user feeling more in control of the website rather than feeling lost and trying to find the title of the page or the homepage link. Development of style sheets and standardised templates allows the content experts to concentrate on the information and its presentation rather than the design.

\section{Text}

Colour, font style and font size are crucial to assist with the readability of text. Minimal distractions assist users in locating what is relevant to them. Navigational aids need to be consistent, unobtrusive but clear and usable for the user.

\section{Identity}

Consistency in the placement of organisation logos, major headings and layout will assist the user with navigation.

\section{Page length}

The length of a page on a website is an individual choice but there are a number of ways of managing longer documents:

- place it on the website as one long document so users can scroll down

- edit it to be a shorter document in a style that is appropriate

- divide the document into two or three separate word documents and make each a webpage and provide links between them for ease of navigation.

\section{Document file size}

Adjusting the size of a file for a webpage is essential. The file size directly affects how long it takes to transmit a webpage over the network from when the page is requested to when it displays. Maximum document weight is measured by counting the file sizes of all images, the page itself and any other content on the page.

\section{Graphics}

A balance of graphics and text improves the webpage and enhances the overall website. Graphics are large in file size and slow down the speed of the page. The aim is to minimise the user's experience of 'latency' i.e. the delay after clicking on a link until the next webpage is displayed. Research has shown that a high level of frustration results from delays in displaying parts of a webpage. The overuse of graphics can increase the latency time and exacerbate the sense of frustration of the user. Selective use of graphics with the file size minimised and compressed will assist this process. JPEG format is more appropriate for photographs and GIF format is more appropriate for graphics or illustrations with text and designs. A limited colour palette will also assist in reducing the file size of graphics. 
Sourced from MLC technology librarian’s notes, March 2000.

Figure 6: some useful ideas and hints to assist with website design

Jakob Nielsen's list of top ten mistakes in web design

1. Using frames.

2. Gratuitous use of bleeding-edge technology.

3. Scrolling text, marquees and constantly running animations.

4. Complex URLs.

5. Orphan pages.

6. Long scrolling pages.

7. Lack of navigation support.

8. Non-standard link colours.

9. Outdated information.

10. Overly long download times.

Source: Nielsen, Jakob 1996, 'Original top ten mistakes in web design, Jakob Nielsen's alertbox (May 1996), available at <www.useit.com/alertbox/9605a.html>, accessed 5 March 2000.

Figure 7: Jakob Nielsen's list of top ten mistakes in web design

\section{Promotion}

MLC Libraries staff have promoted the website to the MLC community in a variety of ways. These activities are listed under the specific target group: staff, students, parents and the wider school library community.

\section{Programs for staff}

The website was formally introduced to staff during a morning tea for all teachers and education support staff. Embedded in the orientation program for all new staff is an introduction to the website. Staff are given a library bookmark (Figure 1) and a booklet as part of their orientation package.

- launch to MLC staff

- staff orientation for new MLC staff each term

- technology showcase for MLC staff

- essential skills program for new MLC staff.

\section{Programs for students}

- orientation for new secondary students each year

- primary students information literacy classes

- secondary students research introductions

- Year 9 Gateway program each term

- international students orientation program each year

- IB Extended essay library support program each year

- Year 7 Information Networkers program each semester

- Year 8 English/Library Personal Investigative Process (PIP) program in Term 2

- research pathfinder introductions to classes

- literature reviews

- Book Week activities. 


\section{Programs for parents}

In 2005 the opportunity to present the MLC Libraries website to parents at a senior school information evening was very successful and an excellent way to have both the recognition and support from the Head of Senior School in demonstrating that one of the ways to impart this knowledge to students was via the parent community. The director presented a brief visual overview of the website and highlighted for parents some important features that would enhance their daughter's senior school experience. Parents were given a handout listing the online resources available from home, a bookmark with the website address, and the five primary links of the website.

- Year 11 and 12 parent information evening.

\section{Programs for library community}

- IASL professional paper

- IB Palms workshop on extended essay program.

\section{Publicity documents}

- bookmark

- staff orientation booklet

- parent information handout

- student information handout.

This promotion process is ongoing and always needs to be a focus of the library team. Different ways to promote the website arise with new opportunities, ideas and technological developments. The website allows the library team to offer students and staff a complete package with easy access to a wide variety of information resources and services. Whenever the opportunity arises, library staff work conscientiously to promote the library website, the extensive online and print resources, and the diverse range of services provided by the library team to the college community.

\section{Issues}

Practical considerations and questions asked during the website development process included some of the following issues. These are arranged in order of importance. The major issues are listed first, followed by minor issues in two groups (i) and (ii). Some of these issues were not resolved, while others have developed during the process. Two years after the initial launch some new issues have arisen. Changes in personnel, technology and curriculum have all impacted on the initial version of the website.

\section{Major}

The major issues that had a significant impact on the development of the website include:

- budget

- catalogue

- collaboration

-- within the library team

-- with other MLC staff 
--with website designer

- decision making process

- legal considerations

-- privacy, photos of students and parent permission

-- copyright on content

-- disclaimers: how watertight is the disclaimer?

-- internet access rather than intranet access

-- site licences for software products

- $\log 0$

- meetings

- promotion

- redesign or update original website

- school protocols

- security of site to ensure accessibility by MLC users only

- staff commitment

- staff organisation

- staff responsibilities

- technical issues

- timeline

- website designer.

Collaboration and legal considerations were two significant areas that impacted on decision-making and the website development process.

\section{Minor (i)}

Some of the minor issues listed may increase with importance as the website process moves into a different phase of development. Minor issues that impacted on the website are listed in two groups. These minor issues include:

- changes in college policy

- college intranet

-- positioning of library on myMLC.net

- curriculum change

- deleting the original website from external agencies

- development of staff skills

- feedback to staff and students

- maintenance and updating the website

-- weekly, monthly, term, annual

- marketing focus of MLC.

Maintenance of the website was not an issue initially, but once the launch and the first few weeks had rolled by then changes needed to be made. The marketing department has continued to have an influence on the site and also on any documents prepared for internal or external use.

\section{Minor (ii)}

The second group of minor issues include:

- archiving versions of the website for the school history 
- development and introduction of EduKate (online learning system)

- evaluation and review process

- future technological developments

- library community: local and international access to the website

- sharing of library information.

Other issues will develop as the website evolves.

\section{Reflection}

The website is a fluid electronic document which can be captured on a CD or DVD at a point in time, but changes every time information is added or deleted from the website. Initially, a CD copy of the website was made in January 2003 and since then a number of versions have been saved and catalogued. The original and most current versions are housed in the library teacher reference collection. Other editions are stored in the college archives as they illustrate the history of the library services at MLC. These website editions reflect the staffing, curriculum and information resources available at that time in the school history and should be documented.

Changes in the school environment that can impact on the website include:

- availability of information resources

- currency of images e.g. student photos

- curriculum change both internal and external

- integration of digital and future technologies

- internal structure of MLC and MLC Libraries

- library environment

- new school uniform

- pathfinders

- personnel

- revision of MLC and MLC Libraries mission statements

- staff responsibilities

- subscriptions to online resources.

Keeping abreast of these changes require regular updating and revision of the website as they all have an impact. These changes need to be accommodated in a well planned website maintenance and revision process.

MLC Libraries website continues to be refined two and a half years since its launch in early 2003. The library education team has continued to have the responsibility of maintaining the website. During the development phase the website team collaborative process was invaluable. All parties involved discussed, contributed and developed their ideas. People learnt to be more accepting of each others opinions and to understand the non negotiable requirements, such as legal issues. The successful outcome of this process was observable as the ideas came together. The site was then enthusiastically received at the staff launch. The website team and all associated staff are very pleased with the success of their achievements as the website is now being used by a variety of MLC staff and students on a daily basis. 
In 2006 the website will require a revision to keep it abreast of developing technologies and changes in curriculum and library fields. In the early years of this millennium the MLC Libraries intranet website has served its purpose but future technological developments may see it superseded by a new mode of curriculum delivery that has not even been discovered.

During the last five years I have had the privilege of leading the MLC Libraries team as their director. I look forward to exploring new horizons for the school library world that we cannot even envisage.

Disclaimer: Any representations or opinions expressed are those of the individual speaker, and not necessarily those of Methodist Ladies' College. 


\section{References}

Grassian, Esther (2000). Thinking critically about world wide web resources'. UCLA College Library Help Guides, Retrieved September 26, 2000.www.library.ucla.edu/libraries/college /help/critical/index.htm

Nielsen, Jakob (1996). 'Original top ten mistakes in web design, Jakob Nielsen's alertbox, retrieved March 5, 2000 from www.useit.com/alertbox/9605a.html

\section{Author note}

Jane Viner is the Director of MLC Libraries, Methodist Ladies’ College Melbourne, Australia. Her present role involves leading a diverse team of information professionals and co-ordinating information resources and services for the MLC community. Jane has a Master of Information Management from Monash University and twenty-five years experience as a teacher librarian and geography teacher in secondary schools, both government and independent. She has had extensive involvement in professional development and has regularly presented at local, national and international library conferences. 
Reproduced with permission of the copyright owner. Further reproduction prohibited without permission. 